\title{
Teaching NeuroImages: Myotonic dystrophy type 1
}

Bingjun Zhang, MD, Yu Yang, PhD, Haotian Wu, MD, Siyuan Liao, MD, and Zhengqi Lu, PhD Neurology ${ }^{\circledR}$ 2018;91:e1269-e1270. doi:10.1212/WNL.0000000000006253
Correspondence

Prof. Lu

Izqzssy@gmail.com

Figure MRI findings in myotonic dystrophy type 1
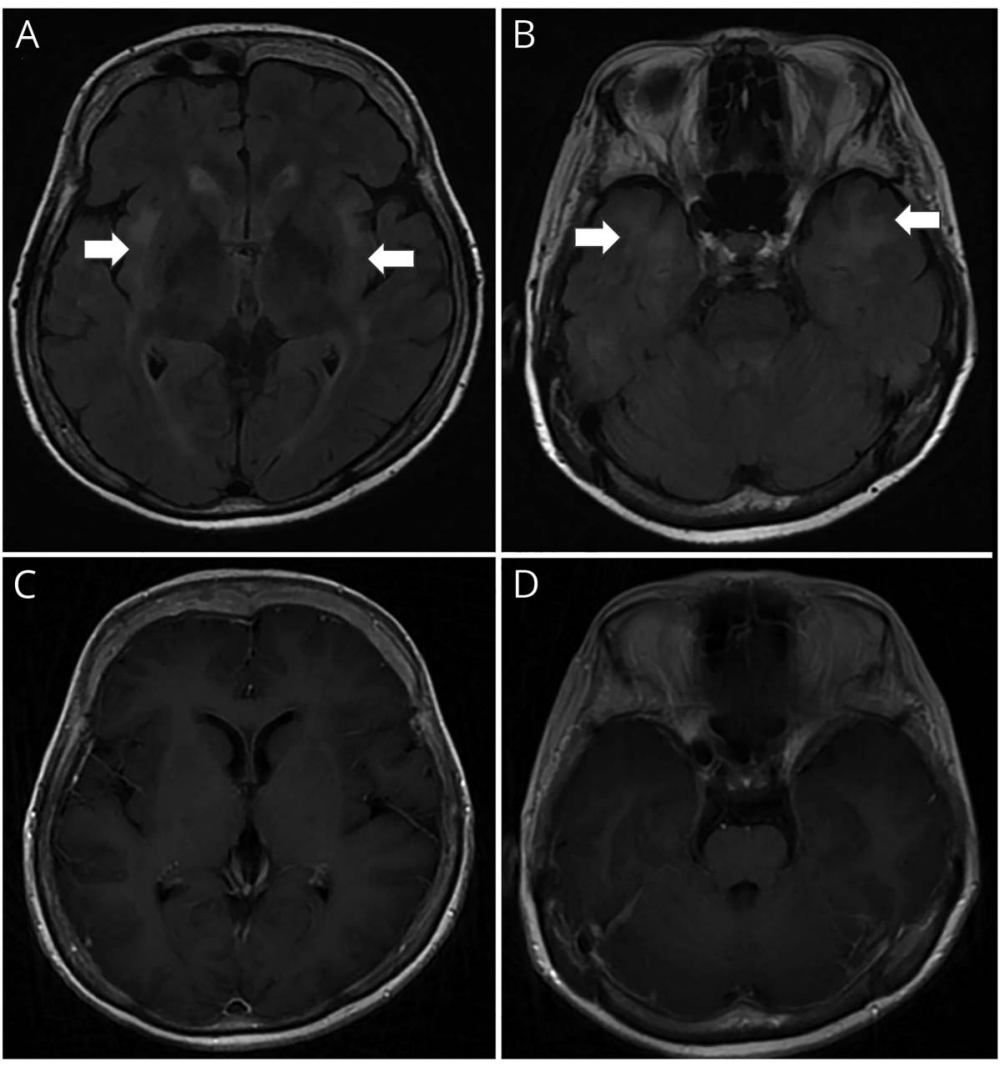

(A) MRI brain axial T2 fluid-attenuated inversion recovery: symmetric, confluent hyperintensity in the anterior temporal lobes white matter (arrow). (B) MRI brain axial T2 fluid-attenuated inversion recovery: bilateral hyperintensity in the external capsules (arrow). (C and D) MRI brain axial T1+ gadolinium: no contrast enhancement.

A 51-year-old woman presented with 2 years' history of progressive distal weakness and muscle atrophy. Clinical and electrophysiological myotonia were found. MRI showed bilateral discrete and confluent areas of abnormal hyperintensity throughout the white matter with predominant involvement of the anterior temporal lobes and external capsules (figure). Genetic testing of DMPK revealed more than 50 CTG repeats in 1 allele, confirming the diagnosis of myotonic dystrophy type 1 (DM1). DM1 is the most common muscular dystrophy observed in adults. ${ }^{1}$ Though MRI in the late stage of DM1, CADASIL and mitochondrial myopathy may be similar, the clinical history for each condition is very different. ${ }^{2}$

\section{Author contributions}

Bingjun Zhang: study concept and design, acquisition and analysis of data, preparation of manuscript including figures. Yu Yang and Haotian Wu: data analysis and interpretation. Siyuan Liao:

\section{MORE ONLINE}

$\rightarrow$ Teaching slides

links.lww.com/WNL/

A683 
acquisition and preparation of data. Zhengqi Lu: study concept and design, data acquisition and interpretation, critical revision.

\section{Study funding}

No targeted funding reported.

\section{Disclosure}

The authors report no disclosures relevant to the manuscript. Go to Neurology.org/N for full disclosures.

\section{References}

1. Emery AE. Population frequencies of inherited neuromuscular diseases-a world survey. Neuromuscul Disord 1991;1:19-29.

2. Sureka J, Jakkani RK. Clinico-radiological spectrum of bilateral temporal lobe hyperintensity: a retrospective review. Br J Radiol 2012;85:e782-e792. 


\section{Neurology}

\section{Teaching NeuroImages: Myotonic dystrophy type 1}

Bingjun Zhang, Yu Yang, Haotian Wu, et al.

Neurology 2018;91; $1269-\mathrm{e} 1270$

DOI 10.1212/WNL.0000000000006253

This information is current as of September 24, 2018

\section{Updated Information \& Services}

\section{References}

Subspecialty Collections

Permissions \& Licensing

Reprints including high resolution figures, can be found at: http://n.neurology.org/content/91/13/e1269.full

This article cites 2 articles, 1 of which you can access for free at: http://n.neurology.org/content/91/13/e1269.full\#ref-list-1

This article, along with others on similar topics, appears in the following collection(s):

MRI

http://n.neurology.org/cgi/collection/mri

Muscle disease

http://n.neurology.org/cgi/collection/muscle_disease Other Education

http://n.neurology.org/cgi/collection/other_education

Information about reproducing this article in parts (figures,tables) or in its entirety can be found online at:

http://www.neurology.org/about/about_the_journal\#permissions

Information about ordering reprints can be found online:

http://n.neurology.org/subscribers/advertise

Neurology ${ }^{\circledR}$ is the official journal of the American Academy of Neurology. Published continuously since 1951, it is now a weekly with 48 issues per year. Copyright @ 2018 American Academy of Neurology. All rights reserved. Print ISSN: 0028-3878. Online ISSN: 1526-632X.

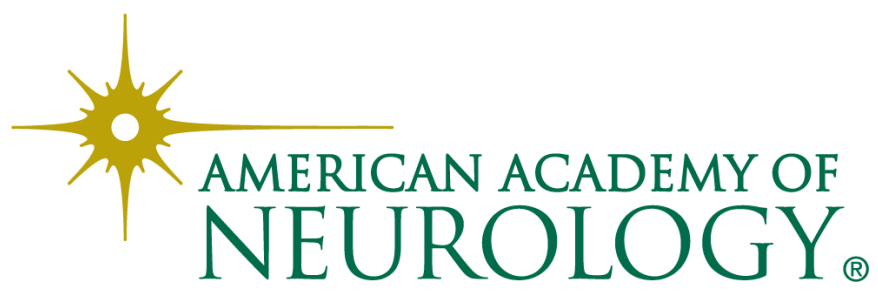

